\title{
Bangkitnya \\ Kaum (Islam) Abangan
}

\author{
Amir Mu'allim
}

The success of PDIP in the last general election is often considered as the success of the subsistent Abangan politic. The Abangan politic becomes a popular term in line with the role of Santri politic in Indonesia political process. Inspite of the controvercy around those terms, the writer of. this book tries to analyze the development of the subsistent Abangan politic. The religion teaching of virtue and humanity should result the inclonclusive and tolerant attitude so that the attitude of destruction, assasination and violence do not represent the religion teaching. The correlation between the dominacy of Abangan politic and the heigtening violence conflict becomes the main focus on this book.

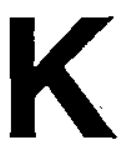

emenangan Rajiv Gandhi dalam pemilu 1984 tampaknya lebih banyak didukung oleh faktor simpati rakyat atas tewasnya almarhumah ibunya, PM Indira Gandhi. Hasil pemilu tersebut telah menempatkan partai Kongres pada posisi mayoritas mutlak, serta tercatat sebagai perolehan kongres terbesar sejak pemilu pertama 1952. Waktu itu kongres mengumpulkan 415 dari 545 kursi yang diperebutkan (Dhurorudin Mashad, 1999:17).

Peristiwa tersebut setidaknya memberikan gambaran tentang hasil pemilu di Indonesia tahun 1999 yang dari perhitungan suara dimenangkan oleh Partai Demokrasi Indonesia Perjuangan (PDIP) pimpinan Megawati Soekarno Putri. Prediksi sementara orang mengatakan bahwa kemenangan Megawati Soekarno Putri tidak lepas dari faktor simpati masyarakat yang dikaitkan dengan meninggalnya almarhum bapaknya, Soekarno.

Hanya yang perlu dicatat di sini adalah istilah rakyat/masyarakat pendukung Me- gawati, yang oleh kalangan tertentu banyak memprediksikan bahwa masyarakat pendukung Megawati kebanyakan dari kelompok abangan. Tertepas dari benar tidaknya persepsi tersebut, persoalan ini perlu menjadi perhatian. Karena istilah abangan, terutama bagi kalangan muslim, mempunyai nilai tersendiri.

Oleh karena itu supaya tidak timbul penilaian sepihak tentang kaum abangan, maka perlu diberikan gambaran tentang apa dan siapa kaum abangan dan bagaimana konfigurasinya dalam kehidupan sosial dan politik.

\section{A. Menyoal Istilah Kaum Abangan}

Persepsi tentang kaum abangan yang secara operasional lebih mengarah pada kelompok Islam memberi kesan bahwa kaum abangan adalah sekelompok pemeluk agamá (Islam) yang tingkat pengetahuan dan amaliyahnya belum sampai pada tingkat tertentu. Istilah "tingkat tertentu" mem- 
punyai pengertian yang luas, dan kadangkala tergantung dari siapa yang mengartikan.

Bachtiar Elendy yang menggunakan konsep Clifford Geertz menilai bahwa sekarang (Indonesia) sedang terbentuk dua kelompok raksasa, yaitu politik santri dan politik abangan priyayi (Republika, 18 Mei 1999). Menurut Bachtiar pemilihan primordial atau religioideologis ini ditekan selama Orde Baru,dan sekarang muncul lagi ketika rezim tersebut rontok.

Dalam studi Geertz, agama abangan menggambarkan sintesa petani antara halhal yang berasal dari kota dan warisanwarisan kesukuan, satu sinkretisme sisasisa lama dari selusin sumber yang ersusun menjadi satu konglomerat untuk memenuhi kebutuhan rakyat yang berjiwa sederhana yang menanam padi di teras-teras yang diairi (Geertz, 1960:229).

Harsja W. Bachtiar yang mengomentari studi Clifford Geertz menyimpulkan bahwa apa yang dalam studi itu disebut sebagai varian agama abangan mengacu kepada apa yang dalam bahasa sehari-hari disebut tradisi rakyat yang pokok, tradisi kaum tani. Inti ritualnya terdiri darislametan atau perjamuan untuk lingkungan tetangga, yang diadakan dengan tujuan agar selamat, yakni satu keadaan psikologis tanpa gangguangangguan emosional. Dengan satu kompleks kepercayaan-kepercayaan tentang roh dan praktik-praktik penyembuhan, varian agama abangan mencerminkan pemberian tekanan pada aspek-aspek animisme dari sinkretisme Jawa secara keseluruhan, yakni sistem keagamaan pada umumnya. Satu ciri orangorang abangan adalah skap masa bodoh terhadap ajaran dan hanya terpesona oleh perincian-perincian upacara (Harsja W. Bachtiar dalam pengantar terjemahan Clifford Geertz, 1981:537).

Apa yang ditangkap oleh Geertz tentang persepsi abangan seolah-olah hanya sebatas pada persoalan ritual dalam bidang aqidah yang menghadirkan sosok kekuatan di luar diri manusia dalam bentuk simbol tertentu (selametan dan semacamnya), akan tetapi dalam perkembangannya istilah abangan sangat kompleks dan sarat dengan pemaknaan yang multi varian. Satu kasus misalnya tentang sinyalemen yang dikemukakan oleh seorang ilmuwan pada pertemuan forum lokakarya di UII yang pada waktu akan mengemukakan sebuah ayat Al-Qur'an mengatakan bahwa "orang seperti saya sebagai orang abangan di bidang ilmu agama, maka tidak apa-apa kalau salah menyebut ayat Al-Qur'an".

Ungkapan tersebut cukup menjadi bukti bahwa istilah abangan tidak sebatas pada penyudutan orang-orang pinggiran yang kering dengan ilmu pengetahuan, akan tetapi juga terjadi pada kaum intelek. Oleh karena itu wajar kiranya jika hasil studiGeertz akhirnya mendapat bantahan. Parsudi buku Suparlan dalam kata pengantàr terjemahan Clifford Geertz tentang abangan, santri, priyayi dalam masyarakat Jawa mengungkap bahwa dengan penggolongan abangan dan santri, kelemahannya tidaklah semata-mata sebagaimana yang dikemukakan oleh Bachtiar. Tetapi juga karena istilah abanganadalah istilah denotatif, dan bukannya istilah refe rensi untuk mengidentifikasi diri sendiri, karena dalam istilah abangan tercakup isirya yang bersifat merendahkan derajat (derogatii), yang biasanya digunakan oleh mereka yang taat menjalankan ibadah agama Istam untuk menamakan mereka yang tidak atau kurang taat. Sedangkan mereka yang tidak taat menjalankan ibadah agama Islam biasanya menamakan diri mereka bukan sebagai abangan tetapi sebagai orang Islam. Istilah santri dapat berfungsi sebagai istilah denotatif maupun sebagai istilah referensi untuk mengidentifikasi diri sendiri. Dengan demikian kalau istilah abangan itu adalah istilah denotatif dan bersifat derogatif, tentunya abangan adalah suatu golongan 
sosial yang bersifat longgar, dan perwu judannya ditentukan oleh konteks hubunganhubungan sosial yang tertentuyaitu dalam kaitannya dengan adanya santri. Dengan demikian juga deskripsinya mengenai struktur sistem simbol abangan, tentunya merupakan deskripsi suatu golongan sosial lainnya yang bersifat absolut, yaitu golongan petani di pedesaan. Dan sesungguh nya Geertz memang berbicara mengenai struktur sosial petani pada waktu dia berbicara mengenai abangan (Parsudi Suparlan dalam Geertz, 1981:x).

Deskripsi abangan yang dikemukakan Geertz, yang kemudian mendapat sanggahan dari berbagai kalangan, mengingatkan akan pentingnya kerangka pemikiran metodologi dalam kaitannya dengan persoalan keagamaan. Hal ini sebagaimana dikemuka kan oleh Sumardi yang menyatakan bahwa dalam penelitian agama, perlu ada suatu pendekatan serta cara-cara yang lebih sesuai, tidak seperti yang lazimnya dipergunakan selama ini dalam penelitian empiris lainnya. Lepas dari masalah setuju atau tidak terhadap suatu pendekatan serta cara yang hendak dibangun dalam disiplin tersendiri, tetapi barangkali yang cukup jelas ialah siapapun yang hendak meneliti masalah keagamaan dari disiplin apa pun, mau tidak mau harus memperhatikan kaidahkaidah tertentu yang selama ini rasanya perlu dirumuskan sebagai bagian "kerangka metodologi" (Sumardi, 1982:2).

Melengkapi persepsi istilah kaum abangan, Dahlan mengemukakan bahwa abangan (aba-an penentang) adalah orang yang penghayatan dan pengamalan serta kesadarannya terhadap hukum agama sangat mengambang, terbatas pada waktu lahir, sunat, kawin dan meninggal. Selain itu tidak ada kaitan kewajiban agama dan tidak pula berusaha untuk mengetahuinya. Dahlan membandingkannya dengan kelompok lain yang disebut mutian (muthi'an) taat, ialah kelompok yang sadar sebagai pengikut suatu agama, mereka berusaha untuk mengetahui dan mendalami ajaran agamanya, dan berusaha pula semaksimal mungkin mengamalkannya (Dahlan, 1992:13).

Pendefinisian abangan versi Zaini Dahlan tersebut kiranya ada kemiripan dengan yang dikemukakan oleh Geertz yang menekankan kepada aspek tradisi ritual keagamaan dalam aktivitas tertentu. Walaupun ada yang sangat mendasar yang memang menjadi parameter umum untuk mengukur tingkat pendalaman terhadap agama (Islam) yaitu tentang kalimat "kesadarannya terhadap hukum agama sangat mengambang".

Namun, perlu disadari bahwa setiap muncul istilah abangan atau istilah Islam abangan berorientasi pada kurangnya pemahaman atau kurangnya kesadaran untuk mengamalkan ajaran-ajaran Islam. Tolok ukur secara umum yang dipahami masyarakat bahwa orang tersebut kurang memąhami atau tidak mengamalkan ajaran Islam secara sempurna seperti tidak shalat, tidak puasa, tidak bisa membaca Al-Qur'an dan lain-lain.

Secara sederhana dapat dikemukakan bahwa istilah abangan atau orang yang dikatakan Islam abangan dapat dikelompokkan ke dalam tiga golongan yaitu:

1. Orang yang mengamalkan ajaran agama tetapi tidak memahami tentang hukumhukum yang ada dalam ajaran agamanya, serta tidak mempunyai kemampuan untuk mempelajari hukum-hukum ajaran agama tersebut. Dalam istilah fiqh dikelompokkan dalam katagori muqollid dan dari segi hukum orang ini dibolehkan dalam status ke-muqolidan-nya.

2. Orang yang mengaku beragama Islam tetapi tidak menjalankan sebagian ajaran Islam, seperti tidak shalat dan tidak puasa. 
3. Orang yang mengamalkan ajaran-ajaran Islam tetapi juga mengamalkan tradisitradisi (seperti yang dianut orang Jawa dengan tradisi slametannya).

Dari tiga golongan tersebut yang masih subur dan banyak menjadi bahan dialog dalam masyarakat adalah golongan yang kedua, dan ini yang menjadi tekanan dalam kaitannya dengan era reformasi pasca pemilu 1999.

\section{B. Kaum Islam Abangan dalam Konfigurasi Sosial}

Al-Qur'an menempatkan manusia pada posisi yang terhormat apabila dibandingkan dengan makhluk-makhluk lain seperti hewan, tumbuhan dan lain sebagainya. Ini dibuktikan dalam firman Allah surat At-Tien ayat 4 , yang maksudnya: "Sesungguhnya Kami telah menciptakan manusia dalam bentuk yang sebaik-baiknya". Penempatan manusia sebagai makhluk yang terhormat yang ditengarai dengan bentuk fisik yang artistik dan aspek lain yang tidak dimiliki oleh makhluk lain seperti akal, dan kemauan menjadikan manusia dapat berbuat seribu tingkah. Dalam posisi seperti ini manakala dibiarkan begitu saja, maka akan terjadi proses dinamisasi yang lepas kontrol, dan tidak mustahil akhirnya manusia terjerembab dalam kehinaan, sebagaimana difirmankan Allah SWT dalam surat al-A'raf ayat 179 yang maksudnya: "Dan sesungguhnya Kami jadikan untuk isi neraka Jahannam kebanyakan darijin dan manusia mereka mempunyai hati tetapi tidak dipergunakannya untuk memahami (ayat-ayat Allah) dan mereka mempunyai mata (tetapi) tidak dipergunakannya untuk melihat (tanda-tanda kekuasaan Allah), dan mereka mempunyai telinga (tetapi) tidak dipergunakannya untuk mendengar (ayat-ayat Allah). Mereka itu sebagai binatang ternak, bahkan mereka lebih sesat lagi. Mereka itulah orang-orang yang lalai".

Dàlam suatu tafsir dijelaskan bahwa bila sifat-sifat demikian menimpa sesuatu bangsa dan negara, maka negara itu nampak menjadi serakah dan penghisap terhadap bangsa dan negara lain. Mereka mempunyai hati (perasaan dan pikiran), tetapi tidak digunakan untuk memahami ayat-ayat Allah. Mereka lupa dan melalaikan bukti-bukti kebenaran Allah pada diri pribadi, pada kemanusiaan dan alam semesta ini, mereka melupakan penggunaan perasaan dan pikiran untuk tujuan-tujuan yang luhur dan meninggalkan kepentingan yang pokok dari kehidupan manusia sebagai pribadi bangsa (Depag RI, 1990 (Jilid.III):652).

Substansi ayat tersebut mengesankan tentang sifat dan karakter manusia yang tidak memiliki sifat-sifat kemanusiaan akibat tidak berfungsinya akal fikiran dan hati mereka sebagai unsur kelebihan yang dikaruniakan Allah yang harus dijunjung tinggi dan diaktifkan pada kondisi yang luhur dan terhormat.

Maraknya berbagai kerusuhan dan tindakan anarkhi yang terjadi di negara Indonesia baik sebelum pemilu (1999) maupun pascapemilu tidak lepas dari konteks ayat 179 surat Al-A'ral tersebut dan apabila dilihat dari segi formalistik, maka pelakupelaku kerusuhan dan tindakan anarkhi tersebut dilakukan oleh kelompok orang yang memiliki identitas Islam. Hanya kalau ditanyakan apakah ajaran Islam membolehkan tindakan-tindakan tersebut? Secara sadar jawaban tersebut mengatakan tidak boleh. Lalu mengapa mereka melakukan itu semua? Asumsi sementara menyatakan karena kelompok mereka yang mengatasnamakan Islam adalah kelompok yang tidak mengerti tentang misi Islam yang sebenarnya atau kelompok Islam yang tidak mengamalkan ajaran-ajaran Islam. 
dan secara sederhana kelompok ini masuk dalam katagori Islam abangan.

Memang dilihat dari segi historis bahwa maraknya berbagai aksi kerusuhan tidak lepas dari andil rezim Orde Baru yangbanyak meninggalkan warisan penjajahan di bidang ekonomi yang mengakibatkan terpuruknya krisis ekonomi, yang bagi kalangan bawah ekonomi adalah sumber segalagalanya sekaligus sumber kenikmatan dan sumber kemaksiatan. Maka tepat kiranya Hadits Nabi saw yang menyatakan bahwa "hampir-hampir kefakiran orang akan menjadi kafir". Kefakiran dalam pengertian sempit dapat berarti krisis ekonomi, akan tetapi kefakiran dalam arti luas adalah orang yang kurang kuat di bidang pemahaman agamanya atau kurang kuat dalam pengamatan agamanya.

Kesimpulan yang dikemukakan oleh Mattulada tentang hubungan antara agama dan ekonomi dalam kehidupan sosial bagi masyarakat Bugis Makassar menyatakan bahwa hubungan agama dan perubahan sosial khususnya hubungan antara doktrin agama dengan sistem tindakan ekonomi (economic behavior) menunjukkan keadaan peralihan yang kritis (Mattulada, dalam Sumardi 1982: 65-66). Nampaknya konsep Islam yang didengungkan 15 abad yang lalu telah ditemukan melalui data-data empiris tentang hubungan antara agama dengan perubahan sosial, dan dalam dataran keindonesiaan masalah agama menjadi sangat komplek karena tidak saja berurusan antarintern (agama Islam sebagai agama mayoritas) akan tetapi juga berurusan dengan antarpemeluk agama yang berbaur dengan istilah kebhinekaan dalam persatuan Indonesia.

Komentar Moeslim Abdurrahman dalam konsep posisi berbeda agama dalam kehidupan sosial di pedesaan kiranya perlu menjadi perhatian yang serius, karena dalam prediksinya antara lain menyatakan bahwa kemajemukan bangsa Indonesia, termasuk dalam hal agama merupakan kekayaan budaya nasional yang dapat menjadikebanggaan. Namun di segi lain, di balik kemajemukan seperti itu sering diungkapkan oleh para ahli sebagai salah satu potensi sosial yang memendam berbagai sumber konflik laten, dan sewaktu-waktudapat saja muncul menjadi bencana nasional sekiranya tidak dapat terkendalikan (Moeslim Abdurrahman, dalam Sumardi 1982: 138).

Longgarnya hubungan dan kehidupan keagamaan di Indonesia menjadikan sistem kehidupan sosial menjadi sulit dibedakan terutama bagi orang/kelompok masyarakat yang tingkat pengamalan agamanya masih kurang, sehingga sederetan kasus seperti munculnya pemberontakan-pemberontakan lokal dengan segala dalih yang ada, kerusuhan-kerusuhan dengan berbagai latar belakang issu yang mengiringinya, sengketa ideologi yang kadang-kadang mencapai titik perkelahian fisik, pertikaian sosial yang melibatkan prasangka-prasangka kesukuan, ketegangan yang terjadi antarhubungan umat beragama dan peristiwaperistiwa lain sejenis yang pernah terjadi di beberapa tempat adalah bukti pernyataan di atas.

\section{Kaum Islam Abangan dalam Konfigurasi Politik}

Ada suatu sinyalemen tentang apakah konflik perlu ada/diciptakan? Pertanyaan ini cukup menarik untuk direspon karena dalam teori manajemen menyatakan bahwa konflik periu diciptakan sebagai upaya untuk mendinamisir kemauan dan keinginan, asalkan munculnya konflik harus diorganisir sehingga tidak terkesan konflik yang liar. Mungkin yang lebih pas dan lebih Islami istilah "konflik" disepadankan dengan istilah "tantangan" agar tidak terkesan ada istilah dua kubu yang saling berbenturan, karena 
istilah konflik yang diterjemahkan di kalangan masyarakat adalah lawan dari akur, damai atau aman.

Dalam teori nilai (Islam) menyatakan bahwa makin banyak tantangan seseorang makin banyak pula alternatif untuk mengambil langkah-langkah untuk merespon tantangan tersebut. Sudah tentu ini terjadi bagi orang-orang yang peduli dengan per ubahan, akan tetapi bagi mereka yangtidak peduli dengan perubahan, akan menganggap tantangan/konflik sebagai sesuatu yang menakutkan.

Dalam sejarah Islam keberhasilan para pemimpin (nabi, sahabat, ulama-ulama besar) tidak lepas dari situasi konflik atau dalam terjemahan yang lebih halus adalah situasi yang penuh dengan tantangan. Pada waktu itu kelompok yang dihadapi Nabi nampak jelas dengan istilah golongan katir dan golongan orang-orang musyrik atau golongan yang beda agama, dan persoalan yang banyak dimunculkan juga jelas yaitu mengarah pada persoalan aqidah.

Lain halnya yang terjadi di negara Indonesia bahwa sumber konflik atau tantangan sangat beragam beriringan dengan keberagamannya manusia itu sendiri. Istilah yang paling populer sampai sekarang persoalan yang paling banyak menjadi sumber konflik adalah karena persoalan SARA (Suku, Agama, Ras dan Antargolongan), walaupun pada kenyataannya banyak persoalan lain yang menjadi sumber pemicu konflik seperti persoalan krisis ekonomi, krisis sosial dan yang tidak kalah pentingnya adalah krisis akhlak.

Situasi politik di Indonesia pada masa sebelum pemilu dan pascapemilu masih berkutat pada prinsip ketidakpuasan, baik yang berkaitan dengan tatanan Orde Baru maupun langkah-langkah yang ditempuh pemerintah sekarang. Munculnya figur pimpinan negara $\mathrm{KH}$. Abdurrahman Wahid yang akrab dipanggil Gus Dur) mempunyai arti tersendiri bagi umat Islam, karena sosok Gus Dur di samping mewakili partai Islam tertentu, juga sebagai wakil kelompok besar umat Islam.

Disadari atau tidak, bahwa warisan kebijakan dan tatanan Orde Baru masih berbaur dengan kebijakan dan tatanan reformasi dan sampai sekarang masih sulit dibedakan. Oleh karena itu apa yang dinyatakan Bachtiar Effendy (Republika, 18 Mei 1999) yang menilai bahwa sekarang sedang terbentuk dua kelompok raksasa yaitu politik santri dan politik abangan priyayi, mendapat komentar dari William $R$ Liddle bahwa sesuatu yang luput dari bidikan analitis Bachtiar adalah munculnya katagori baru pengelompokan politik Indonesia mutakhir yang bukan aliran melainkan pembenturan politik murni. Dua kelompok raksasa itu adalah kelompok status quo dan reformis. Keduanya tidak mewakili golongan primordial, melainkan merangkul atau mengayomi golongan-golongan santri dan abangan priyayi (PDI-P), santri tradisionalis (PKB), dan santri modernis (PAN). Kelompok konservatif juga bersifat nasional dan pan-primordial. la mencontohkan ideologi Golkar adalah pembangunan dan bukan Islam di mana anggotanya terdiri dari semua kepentingan agama, etnis dan daerah (Republika, 20 Mei 1999).

Dominasi partai-partai Islam dalam multipartai tidak secara otomatis menupakan pengelompokan secara eksklusif antara kelompok Islam yang taat dalam berbagai atribut dengan kelompok Islam abangan, akan tetapi sekadar gerakan perimbanganyang mensejajarkan dengan penganut mayoritas bangsa Indonesia yang beragama Islam.

Dan suatu keniscayaan bahwa banyak kelompok Islam abangan yang berada pada wilayah partai-partai Islam dan memainkan peranan besar dalam kancah perpolitikan, dan inilah yang justru harus diwaspadai. 


\section{Kesimpulan}

Pentingnya mengakomodasi kepentingan umat Islam sebagai bagian kehidupan masyarakat yang mempunyai andil besar dalam potensi menggerakkan umat. Oleh karena itu perlu ada komitmen bersama dalam menegakkan panji-panji kebenaran Islam melalui penjelmaan aktivitas dalam komitmen umat dengan menjunjung tinggi nilai-nilai pewahyuan Qur'an.

Parameter muslim dapat dilihat dari kemampuan marealisir prinsip-prinsip ajarannya yang bersendikan pada rukun iman dan rukun Islam. Apabila terjadi pengkhotomian terhadap kedua sendi tersebut, maka tidak mustahil akan terjadi penyimpangan nilai-nilai perilaku seseorang, yang pada gilirannya apabila bentuk penyimpangan itu bersatu dalam kelompok akan menimbulkan gerakan-gerakan anarkhi yang mencemari nilai-nilai Islam itu sendiri dan pada gilirannya akan mengganggu stabilitas nasional.

Kaum Islam abangan yang menjadi label bagi orang/kelompok orang yang kurang mendalami ajaran Islam atau tidak mengerjakan ajaran Islam ada indikasi telah terbentuk dan berbaur dalam komunitas umat baik dalam kehidupan sosial maupun dalam kehidupan politik, dan ini kalau dibiarkan maka terjadinya gerakan disintegrasi bangsa adalah suatu keniscayaan.

Oleh karena itu perlu ada upaya-upaya preventif dengan menyemangati spirit power gerakan da'wah baik da'wah bil haal maupun da'wah bil harakah (keteladanan dan perilaku) agar Islam tidak ditempatkan pada posisi yang marginal.

\section{Daftar Pustaka}

Depag RI dan Universitas Islam Indonesia, Al-Qur'an dan Talsirnya, Jilid III, Yogyakarta, Dana Bhakti Wakaf, 1991.

Depag RI, Al-Qur'an dan Terjemahnya, Jakarta, CV. Kathoda, 1993.

Dahlan, Zaini, Kesadaran Hukum Umat Islam kepada Hukum .Islam dan Peradilan Agama, Seminar Nasional Fakultas Syari'ah UII Yogyakarta, 22 Februari 1992.

Effendy, Bachtiar, B.J. Habibie, Luar Jawa dan Islam, Republika, 18 Mei 1999.

Geertz, Clifford, Abangan, Santri, Priyayi dalam Masyarakat Jawa, Jakarta Pusat: Pustaka Pelajar, 1981.

Liddle, R. William, Sistem Kepartaian di Indonesia Cermin atau Jembatan?, Republika, 20 Mei 1999.

Mashad,Dhurorudin, Agama dalam Kemelut Politik Dilema Sekularisme di India, Jakarta: PT. Pustaka Cidesindo, 1999.

Sumardi,Mulyanto, (Peny.), Penelitian Agama; Masalah dan Pemikiran, Jakarta, Sinar Harapan, Cet. 1, 1982. 